\title{
Commentary: Are the atrial fibrillation ablation guidelines wrong?
}

\section{Patrick M. McCarthy, MD}

In this issue of the Journal, the authors from Washington University report on 376 patients over 10 years who underwent elective concomitant surgical ablation (SA) of atrial fibrillation (AF) and another 498 patients with a history of AF who did not undergo SA. ${ }^{1}$ This is surprising from one of the pioneering SA institutions, because concomitant ablation is a class I or IIa indication according to the guidelines. ${ }^{2-}$

${ }^{4}$ The low use of concomitant ablation, $43 \%$ in this series, raises questions. Society for Thoracic Surgeons (STS) database reports indicate a $51 \%$ use of concomitant SA overall, ${ }^{5} 68 \%$ for mitral operations, ${ }^{6}$ and $>90 \%$ in highvolume centers. ${ }^{7,8}$ They identified more acute kidney injuries in the ablated patients and a worse late prognosis for that subset, but better overall survival for the ablated patients. A report from the STS database also identified a higher risk of renal failure in ablated patients. ${ }^{2}$ Because of selection bias, we do not know whether patients were untreated because of unmeasured confounders, such as frailty, which could impact late survival; because they had large atria and long-standing persistent $\mathrm{AF}$, which would reduce late freedom from $\mathrm{AF}$ (FFAF); or because they were reoperations, and the Cox Maze IV would be very difficult to perform.

The authors propensity-matched 308 patients from both groups. The Cox Maze IV, introduced 20 years ago to shorten the cardiopulmonary bypass (CPB) time compared with the Cox Maze III, was used in $90 \%$ of the operations. ${ }^{9}$ Does it shorten CPB time compared with the Cox Maze III? The clamp and CPB times are longer than those reported

From the Division of Cardiac Surgery, Department of Surgery, Bluhm Cardiovascular Institute, Northwestern University Feinberg School of Medicine and Northwestern Medicine, Chicago, Ill.

Disclosures: Dr McCarthy reported receiving royalties and speaking fees from Edwards Lifesciences and speaking fees from Atricure and Medtronic.

The Journal policy requires editors and reviewers to disclose conflicts of interest and to decline handling or reviewing manuscripts for which they may have a conflict of interest. The editors and reviewers of this article have no conflicts of interest.

Received for publication Jan 29, 2021; revisions received Jan 29, 2021; accepted for publication Feb 1, 2021; available ahead of print Feb 5, 2021

Address for reprints: Patrick M. McCarthy, MD, Division of Cardiac Surgery, Northwestern University, 676 North Saint Clair St, Arkes Family Pavilion, Suite 730, Chicago, IL 60611 (E-mail: Patrick.McCarthy@nm.org).

J Thorac Cardiovasc Surg 2022;164:1858-9

$0022-5223 / \$ 36.00$

Copyright (c) 2021 by The American Association for Thoracic Surgery

https://doi.org/10.1016/j.jtcvs.2021.02.001

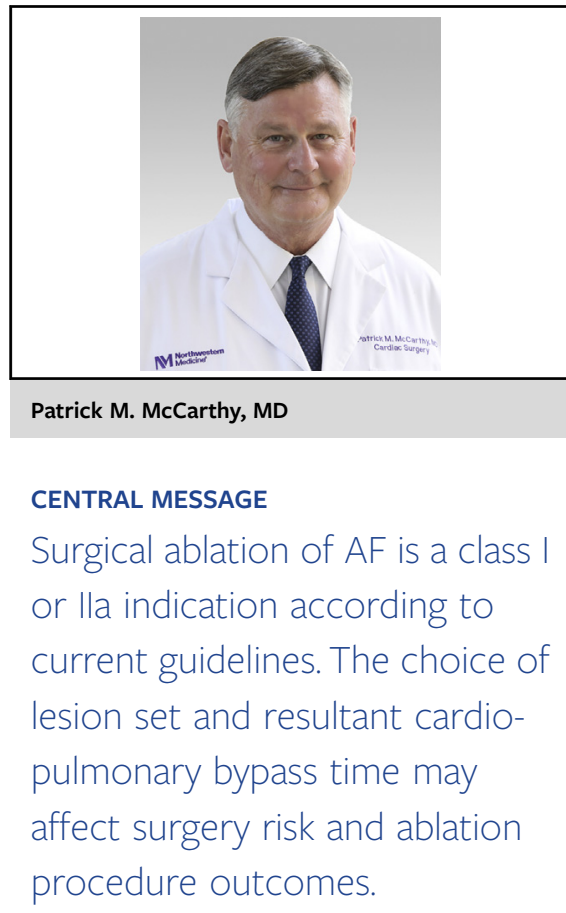

from use of the cut-and-sew Cox Maze III. ${ }^{10-12}$ The matched treated patients had a 68-minute longer CPB time than untreated patients. Prolonged CPB time has been associated with an elevated risk of renal dysfunction and of mortality. ${ }^{13,14}$ We once had untreated AF patients at Northwestern and found a survival advantage with AF treatment. ${ }^{15}$ Therefore, we changed our practice, and technique, to safely add SA for as many patients as possible to improve survival and still achieve a high FFAF. ${ }^{8,16}$ We use cryoablation because it is quick with a simplified lesion set, and we may use left atrial lesions only to reduce cardiopulmonary bypass (CPB) time with a FFAF rate the same as for biatrial lesions in selected patients. ${ }^{17,18}$

All operations require a judgment about risk and benefit, and in cardiac surgery prolonged CPB adds risk. The ideal operation should be efficient to reduce $\mathrm{CPB}$ and the perioperative risks while preserving high effectiveness, in keeping with class I guidelines. However, a technique that adds early risk should be used selectively, conforming more closely to a class IIa guideline. The implications of this article should make us pause and consider 2 choices. Should SA be a class IIa guideline with more selective use, or is there a better way to safely perform SA in most patients and maintain the STS class I recommendation?

\section{References}

1. Bakir NH, Khiabani AJ, MacGregor RM, Kelly MO, Sinn LA, Schuessler RB, et al. Concomitant surgical ablation for atrial fibrillation is associated with 
increased risk of acute kidney injury but improved late survival. J Thorac Cardiovasc Surg. 2022;164:1847-57.e3.

2. Badhwar V, Rankin JS, Damiano RJ Jr, Gillinov AM, Bakaeen FG, Edgerton JR, et al. The Society of Thoracic Surgeons 2017 clinical practice guidelines for the surgical treatment of atrial fibrillation. Ann Thorac Surg. 2017;103:329-41.

3. Otto CM, Nishimura RA, Bonow RO, Carabello BA, Erwin JP III, Gentile F, et al. 2020 ACC/AHA guideline for the management of patients with valvular heart disease: executive summary: a report of the American College of Cardiology/ American Heart Association joint committee on clinical practice guidelines. Circulation. 2021:143:e35-71.

4. Hindricks G, Potpara T, Dagres N, Arbelo E, Bax JJ, Blomström-Lundqvist C, et al. 2020 ESC guidelines for the diagnosis and management of atrial fibrillation developed in collaboration with the European Association of Cardio-Thoracic Surgery (EACTS). Eur Heart J. 2021;42:373-498.

5. Gammie JS, Chikwe J, Badhwar V, Thibault DP, Vemulapalli S, Thourani VH, et al. Isolated mitral valve surgery: the Society of Thoracic Surgeons adult cardiac surgery database analysis. Ann Thorac Surg. 2018;106:716-27.

6. Badhwar V, Rankin JS, Ad N, Grau-Sepulveda M, Damiano RJ, Gillinov AM, et al. Surgical ablation of atrial fibrillation in the United States: trends and propensity-matched outcomes. Ann Thorac Surg. 2017;104:493-500.

7. Badhwar V, Vemulapalli S, Mack MA, Gillinov AM, Chikwe J, Dearani JA, et al. Volume-outcome association of mitral valve surgery in the United States. JAMA Cardiol. 2020:5:1-10.

8. Desai A, Thomas JD, Bonow RO, Kruse J, Andrei AC, Cox JL, et al. Asymptomatic degenerative mitral regurgitation repair: validating guidelines for early intervention. J Thorac Cardiovasc Surg. 2021;161:981-94.e5.

9. Gaynor SL, Diodato MD, Prasad SM, Ishii Y, Schuessler RB, Bailey MS, et al. A prospective, single-center clinical trial of a modified Cox maze procedure with bipolar radiofrequency ablation. J Thorac Cardiovasc Surg. 2004;128: $535-42$.
10. Schaff HV, Dearani JA, Daly RC, Orszulak TA, Danielson GK. Cox-Maze procedure for atrial fibrillation: Mayo Clinic experience. Semin Thorac Cardiovasc Surg. 2000;12:30-7.

11. Arcidi JM Jr, Doty DB, Millar RC. The Maze procedure: the LDS Hospital experience. Semin Thorac Cardiovasc Surg. 2000;12:38-43.

12. McCarthy PM, Gillinov AM, Castle L, Chung M, Cosgrove D III. The Cox-Maze procedure: the Cleveland Clinic experience. Semin Thorac Cardiovasc Surg. 2000; $12: 25-9$.

13. Salis S, Mazzanti VV, Merli G, Salvi L, Tedesco CC, Veglia F, et al Cardiopulmonary bypass duration is an independent predictor of morbidity and mortality after cardiac surgery. J Cardiothorac Vasc Anesth. 2008;22:814-22.

14. Axtell AL, Fiedler AG, Melnitchouk S, D'Alessandro DA, Villavicencio MA Jassar AS, et al. Correlation of cardiopulmonary bypass duration with acute renal failure after cardiac surgery. J Thorac Cardiovasc Surg. 2020;159: $170-8$.

15. Lee R, McCarthy PM, Wang EC, Vaduganathan M, Kruse J, Malaisrie SC, et al. Midterm survival in patients treated for atrial fibrillation: a propensity-matched comparison to patients without a history of atrial fibrillation. J Thorac Cardiovasc Surg. 2012;143:1341-51; discussion $1350-1$.

16. McCarthy PM, Herborn J, Kruse J, Liu M, Andrei AC, Thomas JD. A multiparameter algorithm to guide repair of degenerative mitral regurgitation. J Thorac Cardiovasc Surg. October 10, 2020 [Epub ahead of print].

17. Churyla A, Iddriss A, Andrei AC, Kruse J, Malaisrie SC, Passman R, et al. Biatrial or left atrial lesion set for ablation during mitral surgery: risks and benefits. Ann Thorac Surg. 2017;103:1858-65.

18. Cox JL, Malaisrie SC, Churyla A, Mehta C, Kruse J, Kislitsina ON, et al. Cryosurgery for atrial fibrillation: physiologic basis for creating optimal cryolesions. Ann Thorac Surg. December 3, 2020 [Epub ahead of print].

\title{
Commentary: Concomitant
}

surgical ablation of atrial

fibrillation significantly improves late survival

\author{
Leonid Sternik, MD
}

From the Department of Cardiac Surgery, Leviev Cardiothoracic and Vascular Center, Tel Hashomer, Israel.

Disclosures: The author reported no conflicts of interest.

The Journal policy requires editors and reviewers to disclose conflicts of interest and to decline handling or reviewing manuscripts for which they may have a conflict of interest. The editors and reviewers of this article have no conflicts of interest.

Received for publication Jan 20, 2021; revisions received Jan 20, 2021; accepted for publication Jan 21, 2021; available ahead of print Jan 29, 2021.

Address for reprints: Leonid Sternik, MD, Department of Cardiac Surgery, Leviev Cardiothoracic and Vascular Center, Tel Hashomer, Israel (E-mail: Leonid. sternik@sheba.health.gov.il).

J Thorac Cardiovasc Surg 2022;164:1859-60

$0022-5223 / \$ 36.00$

Copyright $\odot 2021$ by The American Association for Thoracic Surgery

https://doi.org/10.1016/j.jtcvs.2021.01.078

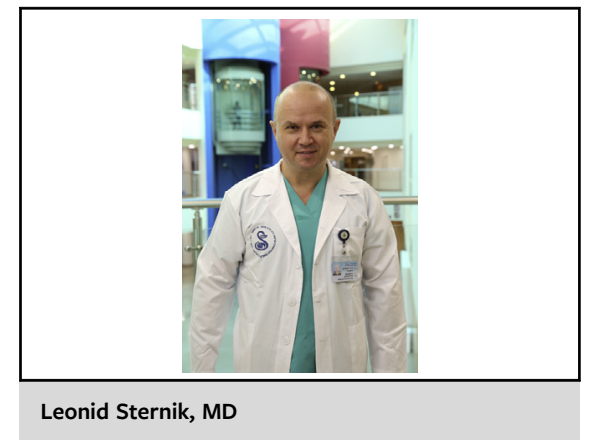

CENTRAL MESSAGE

Concomitant ablation of atrial fibrillation was associated with risk of acute kidney injury (AKI); however, the risks of AKI were offset by the significant survival benefit of concomitant ablation. 